\title{
ПРОФЕСОРУ ВОЛОДИМИРУ МИКОЛАЙОВИЧУ КОЗЬКУ - 70
}

«Лише той Учитель, хто живе так, як навчає»

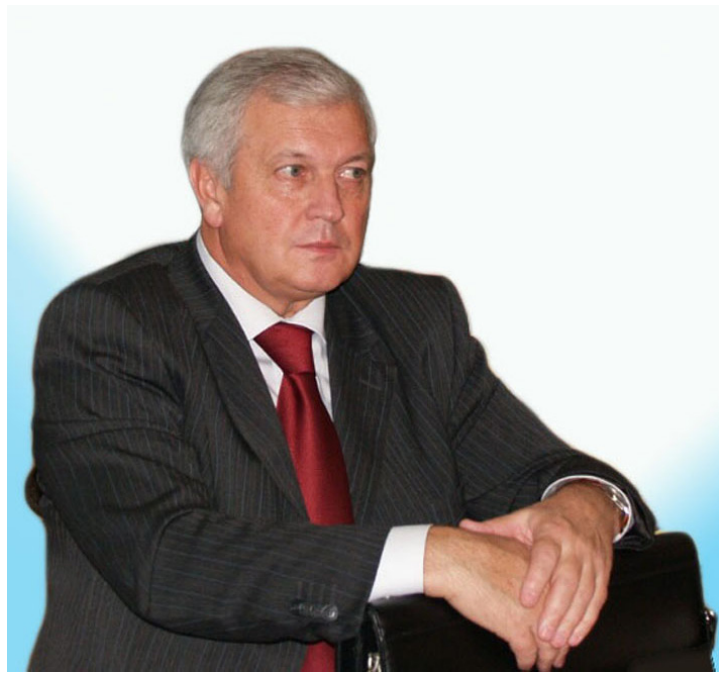

Стисло висвітлено основні біографрічні віхи й творчий доробок профресора В.І. Козька - відомого лікаря-інфекціоніста, педагога, науковця, завідувача кафредри інфрекційних хвороб Харківського національного медичного універcumemy.

Недаремно великий Гете вважав, що тих, у кого вчимося ми, правильно називають вчителями, але не кожний, хто вчить нас, заслуговує на це ім'я. Учитель - це не просто професія, це покликання! Саме таким Учителем з великої літери є відомий вчений-інфекціоніст, лікар вищої категорії, завідувач кафедри інфекційних хвороб Харківського національного медичного університету, доктор медичних наук, профресор Володимир Миколайович Козько, який відсвяткував славний ювілей у березні цього року. Його багаторічна праця не могла залишитися непоміченою та неоціненою.

Народився Володимир Миколайович 18 березня 1943 р. на Далекому Сході в сім'ї військовослужбовця. Перш ніж вступити до вишу, працював робітником на заводі, пройшов дійсну військову службу на фрлоті. Вищу медичну освіту здобув у Харківському медичному інституті, який закінчив з відзнакою, після чого навчався в клінічній ординатурі, а з 1974 р. працював асистентом кафедри інфрекційних хвороб Харківського медичного інституту.
У 1988 р. захистив дисертаційну роботу на тему «Клинико-иммунологические показатели и состояние слизистой оболочки толстой кишки у больных острыми шигеллезами при различных методах лечения» та отримав науковий ступінь кандидата медичних наук, в січні 1996 р. - дисертаційну роботу на тему «Компенсаторно-адаптаційні механізми та можливості їх корекції у хворих різного віку на дизентерію» та здобув науковий ступінь доктора медичних наук, а в 1997 р. - наукове звання професор.

З 1991 р. В.М. Козько очолює касредру інфрекційних хвороб Харківського національного медичного університету. Під керівництвом Володимира Миколайовича в науковій роботі кафедри розроблено напрямок патогенетичного обґрунтування лікування інфекційних хвороб, ведеться активний пошук нових шляхів і можливостей розвитку наукових досліджень. 3 цією метою впроваджується вивчення стану клітинних мембран, мікробіоценозу товстої кишки та методи корекції мікроекологічних порушень, перекисного окислення ліпідів, антиоксидантної системи, показників ендотоксикозу, широко вивчаються особливості метаболічних порушень у хворих на вірусні гепатити та ВІЛ-інсрекцію, розширюється спектр імунологічних і морорологічних досліджень. Подальший розвиток знайшли функціональні методи дослідження дихальних шляхів, капіляроскопічні та термограсрічні методи. Велика увага приділяється вивченню стану компенсаторних механізмів адаптації до інфекційного процесу та удосконаленню медикаментозних і немедикаментозних засобів лікування хвороб, що викликаються бактеріями, вірусами та їх асоціаціями. Серед інших напрямків - поглиблене вивчення патогенетичних, клініколабораторних особливостей нейроінсрекцій, герпесвірусних інфекцій, у т.ч. офртальмогерпесу, бартонельозу, ерліхіозу.

Володимир Миколайович - лікар вищої категорії. Він здійснює консультативну роботу у відділеннях обласної клінічної інфекційної лікарні м. Харкова та інших лікувальних закладах міста й області. В.М. Козько користується значною повагою серед пацієнтів, тому до нього звертаються хворі не тільки з Харкова й області, але й з інших регіонів України.

Під керівництвом В.М. Козька колектив кафедри співпрацює з НДІ імунології та мікробіології ім І.І. Мечникова, 
НДІ загальної та невідкладної хірургії, обласним центром профрілактики та боротьби з ВІЛ/СНІДом, НДІ кріобіології та кріомедицини, іншими фрармацевтичними і науковими закладами. Проведена апробація та впроваджено в практику багатьох медикаментозних препаратів, таких як норфлоксацин, ампісульбін, ерикан, лоперамід, полідеканіт, ентерол, панавір, біфі-срорм, аміксин, арбідол та ін. Широке використання отримала лазерна терапія.

Особливо слід відмітити роботу Володимира Миколайовича щодо підготовки науково-педагогічних кадрів. Він продовжив розвиток школи харківських інфекціоністів, відомої як у нашій країні, так і за її межами. Під його керівництвом підготовлено 2 докторів медичних наук, 17 кандидатів медичних наук, виконуються 1 докторська та 3 кандидатські дисертації.

Крім наукової роботи Володимир Миколайович постійно бере участь у громадському житті ХНМУ, працюючи в різних об'єднаннях і комісіях. 31998 по 2007 рр. йому був доручений почесний обов>язок працювати експертом ВАКу України. Зараз Володимир Миколайович є членом спеціалізованої вченої Ради із захисту докторських та кандидатських дисертацій за спеціальностями «Інфекційні хвороби», «Паразитологія» при Харківській медичній академії післядипломної освіти, головою апробаційної ради з попередньої експертизи дисертаційних робіт з питань вірусології, мікробіології та інфрекційних хвороб ХНМУ. Є членом редколегії журналів «Інфекційні хвороби» та «Експериментальна і клінічна медицина», членом редакційної ради журналів «Гепатологія», «Клиническая иноректология и паразитология», «Врачебная практика», «Актуальная инсректология», заступником голови асоціації інсрекціоністів Харківської області.

За роки науково-дослідницької роботи В.М. Козько надрукував близько 1000 наукових і науково-методичних праць, серед яких є монографії, підручники, навчальні та навчально-методичні посібники. Особисто та у співавторстві отримано 29 патентів на винаходи. Постійно організовує науково-практичні конференції, присвячені проблемам інфректології. Зокрема, у 2016 р. була започаткована й у 2018 р. проводиться вдруге Всеукраїнська консеренція 3 міжнародною участю «Мечниковські читання». Крім того, в 2009 р. під керівництвом професора Козька В.М. вперше в Україні було започатковано Всеукраїнську студентську олімпіаду з інорекційних хвороб.

За успіхи в діяльності Володимир Миколайович неодноразово був відзначений на різних рівнях. У 2015 р. нагороджений Асоціацією інфекціоністів України пам'ятною медаллю Агапіта Печерського «За внесок у боротьбу з інсрекційними хворобами». А з 2017 р. отримує стипендію обласної ради ім. І.І. Мечникова у галузі науки (з медицини та біології).

Треба відзначити особливий талант Володимира Миколайовича у педагогічній діяльності. Він активно впроваджує різні нововведення в навчальний процес, що робить знання доступнішими та привабливішими для кожного студента. Говорячи про Володимира Миколайовича як про талановитого вченого та педагога, не можна не згадати про надзвичайну чуйність і відкритість цієї людини, загострене почуття справедливості, готовність допомогти у скрутну хвилину.

Щиро бажаємо ювілярові, вельмишановному Володимиру Миколайовичу, міцного здоров'я на довгі роки, щастя, гармонії, творчих успіхів, любові та душевного тепла!

Президія Всеукраїнської асоціації інфрекціоністів, колектив кафедри інфекційних хвороб Харківського національного медичного університету, редакція журналу «Інфрекційні хвороби».

\section{PROFESSOR VOLODYMYR MYKOLAIOVYCH KOZKO IS 70}

SUMMARY. Biographic and basic work of professor V.I. Kozko are briefly reflected. He is an infectious diseases doctor, teacher, scientist, head of the Infectious Diseases Department of Kharkiv National Medical University.

Конфрлікту інтересів немає.

Author have no conflict of interest to declare.

Отримано 23.03.2018 р. 